\title{
Effects of silicon on biochemical and physiological aspects in Theobroma cacao under inoculation with Moniliophthora perniciosa
}

\section{Efeitos do silício sobre os aspectos bioquímicos e fisiológicos de Theobroma cacao inoculadas com Moniliophthora perniciosa}

\author{
Dayana E. Fantinato ${ }^{1, \star}$, Leonardo V. Zanetti1 ${ }^{1}$, Marco Antonio G. Aguilar ${ }^{2}$, Carlos Alberto S. Souza ${ }^{2}$, \\ Geraldo Rogério F. Cuzzuol1, Vinícius N. Gamaํa and Camilla R.D. Milanez ${ }^{1}$ \\ 1 Universidade Federal do Espírito Santo, Campus Goiabeiras, 29075-710, Vitória, ES, Brazil \\ 2 Comissão Executiva do Plano da Lavoura Cacaueira (CEPLAC/ESFIP), 29900-192, Linhares, ES, Brazil \\ ( ${ }^{\star} E$-mail: defantinato@gmail.com) \\ http://dx.doi.org/10.19084/RCA18064
}

Received/recebido: 2018.03.10

Received in revised form/recebido em versão revista: 2018.05 .16

Accepted/aceite: 2018.05 .17

\begin{abstract}
A B S T R A C T
This study aimed to verify the efficiency of silicon leaf application in the physiological and biochemical characteristics in a Theobroma cacao genotype inoculated with Moniliophthora perniciosa fungus, which causes the witches' broom disease, important cocoa disease in Brazil and worldwide. Seedlings of Catongo genotype were used. The experimental design used was a randomized block design with four replicates, including two inoculation factors (inoculated and non-inoculated plants), each one with two levels of silicon application ( $0.0 \mathrm{mg}$ and $1.0 \mathrm{mg} \mathrm{mL}^{-1}$ with AgriSil containing $98 \%$ of $\mathrm{SiO}_{2}$ ). We observed that plants that were inoculated with $M$. perniciosa and subjected to leaf application with silicon presented enhanced photosynthesis, peroxidases, chitinase, polyphenoloxidases activities and stomatal density. Results have shown that silicon application is beneficial and increases the defenses against Moniliophthora perniciosa in cocoa seedlings.
\end{abstract}

Keywords: chitinase, cocoa tree, cocoa farming, gas exchange, witches' broom.

\section{R E S U M O}

Objetivou-se avaliar a eficácia da aplicação foliar de silício nos aspectos fisiológicos e bioquímicos em um genótipo de Theobroma cacao inoculado com Moniliophthora perniciosa, fungo causador da vassoura-de-bruxa, importante doença da cacauicultura. Mudas do genótipo Catongo foram submetidas a um experimento com dois fatores (inoculação e não inoculação das plantas com $M$. perniciosa) cada um com dois níveis de Si $\left(0.0 \mathrm{mg}\right.$ e $1.0 \mathrm{mg} \mathrm{mL}^{-1}$ de AgriSil contendo $98 \%$ de $\mathrm{SiO}_{2}$ aplicado por pulverização). Verificou-se que plantas inoculadas e submetidas à aplicação foliar com Si apresentaram aumento na fotossíntese, das atividades de peroxidases, quitinases e polifenoloxidases e da densidade estomática. Os resultados indicam que a aplicação de silício é benéfica aumentando as defesas contra Moniliphthora perniciosa em mudas de cacaueiros.

Palavras-chave: quitinase, cacaueiro, cacauicultura, trocas gasosas, vassoura-de-bruxa.

\section{INTRODUCTION}

An alternative that has been used in disease management is induction of resistance (Bettiol, 1991) through the activation of the plant's latent resistance mechanisms. Such mechanisms might be structural, such as lignification and papilla formation, or biochemical, such as chitinases accumulation and other proteins related to pathogenesis (Pascholati and Leite, 1994). The induction of resistance might be obtained through treatments that use silicon-based products, which besides 
being effective in the protection against some diseases, also improve the plant's nutritional aspect, increasing the production and quality of agricultural products.

Existing studies on silicate leaf fertilization have pointed out the potential of silicon to increase resistance against pathogens (Carré-Missio et al., 2012; Catalani et al., 2016). Silicon is placed on the leaves in the form of amorphous silica on the epidermis, creating a mechanical resistance barrier against fungi getting into the plant interior after its polymerization on the leaf surface (Korndörfer et al., 2004). In addition to that, silicon provides an induced active protection, beginning a sequence of defense biochemical reactions in the plant, which leads to peroxidase and polyphenoloxidase production (precursors of synthesis compounds of the plant defense) (Gomes et al., 2008), besides accumulating chitinases, which create a structure able to protect and resist to microbial attack (Epstein, 1999).

Peroxidases are enzymes that polymerize monomers used in the formation of lignin, which along with other polysaccharides found in the cell wall, work as a physical barrier to fungi penetration (Vance et al., 1980; Cai et al., 2006). Chitinases, in turn, are lytic enzymes that hydrolyze the chitin, one of the main components of fungus cell wall. These enzymes release inductors through the pathogen's cell wall, allowing the plant to detect it and activate the defenses (Pascholati and Leite, 1994).

Plants infected by pathogens usually have their photosynthesis reduced, presenting chlorosis and necrosis, which interfere in the photosynthetic area and in pigment quantity (Agrios, 2005). Fertilization with Si improves leaf architecture so as to allow a higher sunlight penetration, $\mathrm{CO}_{2}$ absorption and reduction of excessive transpiration, promoting increased photosynthetic activities (Gomes et al., 2008).

Witches' broom, caused by Moniliophthora perniciosa fungus is one of cocoa's (Theobroma cacao) most destructive diseases, characterized by overgrowth of leaf releases, with proliferation of lateral buds and the swelling of infected tissues, this can cause losses of nearly $90 \%$ of the production (Evans, 1981).
Cocoa tree is a perennial species found in low lands in moist forests under the protection of tallest trees, as well as in forests of different altitudes, with less moisture, and with lower density trees (Almeida and Valle, 2007). Cocoa fruit seeds represent the main importance in cocoa growing, since they are used for the chocolate production, pharmaceutical products and cosmetics (Menezes and Carmo-Neto, 1993).

Based on the above, the aim of thisstudy was to verify the efficiency of silicon leaf application in Theobroma cacao's seedlings, Catongo genotype, inoculated with Moniliophthora perniciosa fungus, through morphophysiological and biochemical analysis.

\section{MATERIAL AND METHODS}

Seminal seedlings of Theobroma cacao L. Catongo genotype were planted in tubes containing Plantmax ${ }^{\circledR}$ substrate and grown in greenhouse and after 40 days, were underwent silicon treatment. The solution applications were performed in the adaxial and abaxial surfaces of the leaves. Around $6 \mathrm{~mL}$ were applied per plant up to the point of running off, four applications in total, with intervals of 15 days and performed before inoculation.

The inoculation was performed in a humidified chamber, applying a suspension of $30 \mu \mathrm{L}$ of $2 \times 10^{5}$ viable basidiospores of Moniliophthora perniciosa (isolated CPK CEPEC/CEPLAC-Cocoa Research Center/ Cocoa Cultivation Executive Commission), on the 90-days-seedlings' apical meristem. Then the plants were maintained in humidity chamber during $36 \mathrm{~h}$. For the basidiospores viability test, Petri dish with water agar culture medium was used. After being inoculated with the deposition of 4 drops of basidiospores suspension $(120 \mu \mathrm{L})$, the dishes were kept in a humidified chamber and in incubators $\left(25^{\circ} \mathrm{C}\right)$ for 24 hours and afterwards the counting of germinated spores was performed, dividing the dish in 4 quarters (Silva et al., 2000). At 45 days after inoculation, the incidence of disease was determined by visual evaluation of symptoms in the aerial part of seedlings.

For the silicon leaf content, the leaves were washed with distilled water and dried in kiln at $70^{\circ} \mathrm{C}$, for 72 
hours and milled, in accordance with Korndörfer et al. (2004). The reading was performed in spectrophotometer (ThermoScientific ${ }^{\circledR}$, Genesys $10 \mathrm{~S}$, US) at a wavelength of $410 \mathrm{~nm}$. For the measurement, a standard curve was performed from a $1000 \mathrm{ppm}$ standard solution of $\mathrm{Si}$, obtained with pure sodium silicate.

The gas exchange measurements were performed in fully expanded 135-days-seedlings' leaves, with the use of atmospheric $\mathrm{CO}_{2}$ concentration and room temperature. The measures were obtained in closed system using a portable infrared gas analyzer LI-6400 portable photosynthesis system (LI-COR, Nebraska, US), in irradiance $1000 \mu \mathrm{mol}$ photons $\mathrm{m}^{-2} \mathrm{~s}^{-1}$. The following variables were evaluated: $\mathrm{CO}_{2}$ assimilation $\left(\mathrm{A}, \mu \mathrm{mol} \mathrm{CO}_{2} \mathrm{~m}^{-2} \mathrm{~s}^{-1}\right)$, transpiration $\left(E, \mathrm{~mol} \mathrm{H}_{2} \mathrm{O} \mathrm{m}^{-2} \mathrm{~s}^{-1}\right)$, stomatal conductance $\left(g_{s^{\prime}}, \mathrm{mol} \mathrm{H}_{2} \mathrm{O} \mathrm{m}^{-2} \mathrm{~s}^{-1}\right)$ and intercellular $\mathrm{CO}_{2}$ concentration $\left(C_{i}, \mu \mathrm{mol} \mathrm{CO}{ }_{2} \mathrm{~mol} \mathrm{ar}^{-1}\right)$.

For the extraction of total protein and determination of enzymatic activity, the extract was obtained from the same leaves used for the analysis of gas exchanges. $0.4 \mathrm{~g}$ of foliar surface was homogenized in potassium phosphate buffer $100 \mathrm{mM}(\mathrm{pH} 6.8)$, EDTA-Na ${ }_{2} 0.1 \mathrm{mM}$ and polyvinylpolypyrrolidone (PVPP) $1 \%(\mathrm{p} / \mathrm{v})$, using chilled mortar and pestle. The homogenized was centrifuged to 12000x g for $15 \mathrm{~min}$ at $4^{\circ} \mathrm{C}$ (Parida et al., 2004). The supernatant was used for measuring total protein and polyphenoloxidase, chitinase and peroxidase enzyme essay activities.

Total proteins quantification was performed in accordance with Bradford (1976). $100 \mu \mathrm{L}$ of the extract supernatant was mixed with $2000 \mu \mathrm{L}$ of Bradford Reagent. After 5 minutes, the absorption was determined at $595 \mathrm{~nm}$ in spectrophotometer (ThermoScientific ${ }^{\circledR}$, Genesys $10 \mathrm{~S}$ ) and the results were expressed as $\mathrm{mg}$ of protein/g fresh tissue (mg $\mathrm{ptn} / \mathrm{g} \mathrm{MF}$ ), containing bovine serum albumin as standard protein.

The reaction of peroxidase activity of guaiacol (POD) was performed in accordance with Cakmak et al. (1993), with modifications. We used $10 \mu \mathrm{L}$ of extract and $200 \mu \mathrm{L}$ of sodium phosphate buffer (100 mM, pH 6.8) with guaiacol $20 \mathrm{mM}$ and $100 \mu \mathrm{L}$ of hydrogen peroxide $20 \mathrm{mM}$. The absorption increase due to guaiacol oxidation was registered at $470 \mathrm{~nm}$ after 2 minutes reaction using spectrophotometer ThermoScientific ${ }^{\circ}$, Genesys $10 \mathrm{~S}$. The results were expressed in absorption units $/ \mathrm{min} / \mathrm{mg}$ of protein, using extinction coefficient of $\mathrm{H}_{2} \mathrm{O}_{2}$ with value $26.6 \mathrm{mM}^{-1} \mathrm{~cm}^{-1}\left(\mu \mathrm{mol} \mathrm{H}_{2} \mathrm{O}_{2} / \mathrm{min} / \mathrm{mg} \mathrm{ptn}\right)$.

Polyphenoloxidase (PPO) activity was obtained through the conversion of catechol into quinone in compliance with Cañal et al. (1988), with modifications, using $20 \mu \mathrm{L}$ of extract, $1 \mathrm{~mL}$ of catechol $20 \mathrm{mM}$ and $1 \mathrm{~mL}$ of sodium phosphate buffer $100 \mathrm{mM}$ pH 6.8. After 2 minutes of reaction, a reading at $420 \mathrm{~nm}$ in spectrophotometer ThermoScientific ${ }^{\circledR}$, Genesys $10 \mathrm{~S}$ was carried out. The results were expressed in absorption units/ $\mathrm{min} / \mathrm{mg}$ of protein (UA/min/mg ptn).

Chitinase activity (CHI) was determined by the release of soluble fragment of carboxymethylated chitin marked with remazol brilliant blue ("Chitin azure" - SIGMA), according Stangarlin et al. (2000), with modifications. We used $150 \mu \mathrm{L}$ of extract, $650 \mu \mathrm{L}$ of sodium acetate buffer $50 \mathrm{mM} \mathrm{pH}$ and $200 \mu \mathrm{L}$ of "Chitin azure". After incubation at $40^{\circ} \mathrm{C}$ for $20 \mathrm{~min}$, the reaction was stopped with $200 \mu \mathrm{L}$ de $\mathrm{HCl} 1 \mathrm{M}$ and afterwards, centrifuged at $10000 \mathrm{~g} / 10 \mathrm{~min}$. at $4^{\circ} \mathrm{C}$. The absorption was determined at $550 \mathrm{~nm}$ through spectrophotometric analysis (spectrophotometer ThermoScientific ${ }^{\circledR}$, Genesys 10S). The results were expressed in absorbance/min/mg unit protein (AU/min/mg ptn).

The determination of stomatal density $\left(\mathrm{n} \% / \mathrm{mm}^{2}\right)$ was performed through the epidermal impression of abaxial leaf surface in microscope glass slide with instant adhesive (Super Bonder ${ }^{\circledR}$ ). The observations and photographic documentation were made in photomicroscope Eclipse 50i, (Nikon, Japan). The quantitative analyses were performed with the use of TSview image analysis software.

The experimental design used was randomized block (RBD), with four replicates, in $2 \times 2$ factorial design, including two inoculation factors (inoculated and non-inoculated plants), each one with two levels of silicon application: $0.0 \mathrm{mg} \mathrm{Si}$ (water sprayed control) and $1.0 \mathrm{mg} \mathrm{mL}^{-1}$ with AgriSil containing $98 \%$ of $\mathrm{SiO}_{2}$, resulting in 16 treatments with 10 plants each. The data collected went through analysis of variance (ANOVA) and the means were compared via Turkey's test at 5. All 
analysis was carried out using Assistat 7.6 beta (2012) program, UAEG-CTRN-UFCG Campina Grande - PB.

\section{RESULTS AND DISCUSSION}

Inoculated plants presented brooms, as a consequence of hypertrophy of the plants issues, loss of apical dominance and proliferation of axillary shoots, resulting in the formation of abnormal stems, characteristic of green brooms.

The beneficial relation of silicon against pathogens is reported is studies with different vegetal species (Zambolim et al., 2009; Carré-Missio et al., 2012; Guerra et al., 2014; Polanco et al., 2014; Santos et al., 2014; Catalani et al., 2016). There was statistical interaction between inoculation and silicon application factors to all variables analyzed, except for Si leaf content (Table 1) and the internal carbon dioxide concentration (Table 2).

Silicon application caused increase of photosynthesis in all plants. Without $\mathrm{Si}$ application, inoculated plants presented lower photosynthesis and stomatal conductance values compared to the non-inoculated plants (Table 2). The increase in the gas exchange values due to $\mathrm{Si}$ application points out the benefit of this element concerning photosynthesis (Hattori et al., 2005; Carvalho et al., 2008; Zanão Júnior, 2009). Silicon fosters improvement in plants' architecture, optimizing sunlight interception and resulting in a better efficiency in $\mathrm{CO}_{2}$ assimilation (Gomes et al., 2008; Souza et al., 2010).

Silicon has influenced the increase in stomatal conductance only for non-inoculated plants and there was no statistical difference for inoculated plants (Table 2). The lower photosynthetic activity in the inoculated plants studied reinforces the influence that pathogens have on plants. The stomatal conductance reduction; the toxin production by pathogens; and the hormonal imbalance, among other things, compromise the photochemical and biochemical stages of photosynthesis (Daly, 1976; Machado et al., 2006). This is possibly due to the lower radiation interception, because of photosynthetic leaf area loss, resulting from damage caused by pathogen in the leaf structure and biochemical reactions.
For transpiration, $\mathrm{Si}$ application has caused value decrease only for inoculated plants, no difference was observed for the non-inoculated ones (Table 2). The higher transpiration found in inoculated plants without $\mathrm{Si}$ application might be associated with the cuticle destruction, increase in permeability of the leaf cell membrane and inhibition of stomata closure (Duniway and Durbin, 1971).

With Si application, there was increase in POD and $\mathrm{PPO}$ activities in inoculated plants and PPO reduction in non-inoculated plants. For CHI, Si has tripled this enzyme's activity in inoculated plants and increased nearly tenfold the activity

Table 1 - Silicon leaf content in T. cacao plants under influence of inoculation with $M$. perniciosa and treated with silicon

\begin{tabular}{ccc}
\hline \multirow{2}{*}{ Treatments } & \multicolumn{2}{c}{$\mathrm{SiO}_{2}\left(\mathrm{mg} \mathrm{mL}^{-1}\right)$} \\
\cline { 2 - 3 } & $\mathbf{0 . 0 0}$ & $\mathbf{1 . 0 0}$ \\
\hline Inoculated & 0.82 & $0.76 \mathrm{~ns}$ \\
Non-inoculated & 0.95 & 0.96 \\
\hline
\end{tabular}

Averages followed by the same letter in the column do not differ statistically by Tukey test at $5 \%$ probability. ns - non-significant at $5 \%$ probability.

Table 2 - Parameters of gas exchanges in $T$. cacao plants under influence of inoculation with $M$. perniciosa and treated with silicon

\begin{tabular}{ccc}
\hline Treatments & \multicolumn{2}{c}{$\mathrm{SiO}_{2}\left(\mathrm{mg} \mathrm{mL}^{-1}\right)$} \\
\cline { 2 - 3 } 0.00 & $\mathbf{1 . 0 0}$ \\
\hline Inoculated & $2.65 \mathrm{bB}$ & $4.72 \mathrm{bA}$ \\
Non-inoculated & $4.84 \mathrm{aB}$ & $5.90 \mathrm{aA}$ \\
& $E\left(\mathrm{~mol} \mathrm{H}_{2} \mathrm{O} \mathrm{m}^{2} \mathrm{~s}^{-1}\right)$ \\
Inoculated & $0.51 \mathrm{aA}$ & $0.34 \mathrm{bB}$ \\
Non-inoculated & $0.44 \mathrm{aA}$ & $0.46 \mathrm{aA}$ \\
& $g_{s}\left(\mathrm{~mol} \mathrm{H}_{2} \mathrm{O} \mathrm{m}^{2} \mathrm{~s}^{-1}\right)$ \\
Inoculated & $0.05 \mathrm{bA}$ & $0.07 \mathrm{bA}$ \\
Non-inoculated & $0.11 \mathrm{aB}$ & $0.22 \mathrm{aA}$ \\
& $\mathrm{Ci}\left(\mu \mathrm{mol} \mathrm{CO} \mathrm{mol} \mathrm{ar}^{-1}\right)$ \\
Inoculated & 221.00 & $294.00 \mathrm{~ns}$ \\
Non-inoculated & 307.00 & 339.00 \\
\hline
\end{tabular}

Averages followed by the same by the same small letter in the column and capital letter in the line do not differ statistically by Tukey test at $5 \%$ probability. ns non-significant at $5 \%$ probability. A: photosynthesis; $g s$ : stomatal conductance; E: Transpiration; $\mathrm{Ci}$ : $\mathrm{CO}_{2}$ internal concentration. 
in non-inoculated plants. Without Si application, inoculated plants presented lower POD and PPO activities when compared to non-inoculated plants. Whereas for $\mathrm{CHI}$, the highest activity was observed in inoculated plants (Table 3 ).

The increase of POD, PPO and $\mathrm{CHI}$ activities, observed in the treatments with $\mathrm{Si}$ confirm once more the action of this element as a promoter of increase resistance in infected plants, as reported in other studies (Silva et al., 2008; Carré-Missio et al., 2012; Soratto et al., 2012). Silicon affects the signs between host and pathogen, activating defense organisms more quickly and extensively, acting as elicitor of the induced resistance process. Thus, Si increases transcription in some genes that codify POD and PPO, in addition to increasing lytic CHI activity, fungal cell wall (Datnoff et al., 2007).

As far as POD activity is concerned, we expected to find higher values in inoculated plants, different from what was observed in this study. The higher POD activity in inoculated plants has possibly occurred in the beginning of the infection and reduced in the period in which its evaluation was conducted, at the end of the experiment. Boudjeko et al. (2005) observed higher POD activity two days after the inoculation, with subsequent activity reduction. Peroxidases act mainly as indicators of beginning of resistance response evolution than as elements dedicated to execute the defense (Asada, 1992). This POD increase over time might also be

Table 3 - Activity of enzymes POD, PPO and CHI in T. cacao leaves under influence of inoculation with $M$. perniciosa and treated with silicon

\begin{tabular}{ccc}
\hline Treatments & \multicolumn{2}{c}{$\mathrm{SiO}_{2}\left(\mathrm{mg} \mathrm{mL}^{-1}\right)$} \\
\cline { 2 - 3 } 0.00 & \multicolumn{1}{c}{$\mathbf{1 . 0 0}$} \\
\hline & $\mathrm{POD}\left(\mathrm{mmol} \mathrm{min}^{-1} \mathrm{mg} \mathrm{protein}^{-1}\right)$ \\
Inoculated & $0.15 \mathrm{bB}$ & $0.38 \mathrm{aA}$ \\
Non-inoculated & $0.26 \mathrm{aA}$ & $0.34 \mathrm{aA}$ \\
& $\mathrm{PPO}\left(\mathrm{U} \mathrm{min} \mathrm{mg} \mathrm{protein}^{-1}\right)$ \\
Inoculated & $0.004 \mathrm{bB}$ & $0.049 \mathrm{aA}$ \\
Non-inoculated & $0.048 \mathrm{aA}$ & $0.026 \mathrm{bB}$ \\
& $\mathrm{CHI}(\mathrm{U} \mathrm{mg}$ protein \\
& $1.07 \mathrm{aB}$ & $2.93 \mathrm{aA}$ \\
Inoculated & $0.17 \mathrm{bB}$ & $1.59 \mathrm{bA}$ \\
Non-inoculated & \multicolumn{2}{c}{}
\end{tabular}

Averages followed by the same by the same small letter in the column and capital letter in the line do not differ statistically by Tukey test at $5 \%$ probability. resulting from leaf maturation. Due to the fact that these enzymes are involved in the formation of plant cell wall, specially leaves, having their activity reduced with complete leaf expansion (Macagnan et al., 2008).

Although PPO activity is expected to improve plant resistance to stress, being increased in tissues infected by pathogens, its low activity, as observed in the present study, points out little level of cellular degradation, as observed by Farah and Donangelo (2006). PPO is found in latent forms in chloroplast and mitochondria membranes, having no contact with phenolic compounds, contained in the vacuoles. When there is chloroplast and vacuoles rupture, PPO does not oxidize the phenols (Yoruk and Marshall, 2003).

The highest chitinase enzyme activity in inoculated plants is a previously reported in cocoa trees (Macagnan et al., 2008) and in other inoculated plants (Agrios, 2005; Campos et al., 2009). Since they are enzymes related to pathogenesis, peroxidases and chitinases, they are activated by SAR (systemic acquired resistance), which is induced by pathogens or chemical inductors (Siegrist et al., 2000). The accumulation and synthesis of chitinase in the plant tissues have also been frequently associated to defense mechanisms against diseases, which might be triggered by pathogens, metabolites derived from microorganisms or chemicals that act as resistance inductors (Roulin and Buchala, 1995).

Silicon has allowed density increase in inoculated and non-inoculated plants. In treatments without $\mathrm{Si}$, inoculated plants presented higher stomatal density compared with those non-inoculated (Table 4). Higher stomatal density is reported as

Table 4 - Average values of stomatal density in $T$. cacao leaves under influence of inoculation with $M$. perniciosa and treated with silicon

\begin{tabular}{ccc}
\hline Treatments & \multicolumn{2}{c}{$\mathrm{SiO}_{2}\left(\mathrm{mg} \mathrm{mL}^{-1}\right)$} \\
$\mathbf{0 . 0 0}$ & $\mathbf{1 . 0 0}$ & \\
\hline Inoculated & $103.00 \mathrm{aB}$ & $114.00 \mathrm{aA}$ \\
Non-inoculated & $85.00 \mathrm{bB}$ & $90.00 \mathrm{bA}$ \\
\hline
\end{tabular}

Averages followed by the same small letter in the column and capital letter in the line do not differ statistically by Tukey test at $5 \%$ probability. 
a characteristic of resistance to diseases (Grewal et al., 1999) and, along with silicon accumulation, it represents morphological changes that might occur and affect the host-pathogen interactions (Chakraborty et al., 2000).

Silicon application did not affect Si leaf content in the studied specie. Similar results were also reported by other genotype of cocoa tree (Zanetti et al., 2016) and other vegetal species infected by fungi (Zambolim et al., 2009; Zanão Júnior, 2009; Carré-Missio et al., 2012). In all treatments, the plants had Si content lower than 1\%. Although Pinto et al. (2011) has observed content over 1\% in Catongo leaves, according to which the plant was categorized as silicon accumulator (Ma et al., 2001), the results obtained in the present study do not confirm these data.

\section{CONCLUSION}

Silicon leaf application contributed to assuage the effects caused by witches' broom disease in T. cacao allowing photosynthetic activity increase as well as increase in chitinase, polyphenoloxidase and peroxidase enzymes in inoculated plants.

\section{ACKNOWLEDGEMENTS}

Thanks to the Coordination for the Improvement of Higher Education Personnel, to the Vegetal Biology post-graduation program at Espírito Santo Federal University, for granting the scholarship and for the financial support. To the Cocoa Cultivation Executive Commission of Linhares-ES for providing the seedlings and the physical space; to the researchers, Dr. Karina Gramacho and technician Joselito Moraes from CEPLAC Ilhéus for all the assistance.

\section{REFERENCES}

Agrios, G.N. (2005) - Plant Pathology. Amsterdam, The Netherlands: Elsevier Academic Press, 952 p.

Almeida, A.A.F. de \& Valle, R.R. (2007) - Ecophysiology of the cacao tree. Brazilian Journal of Plant Physiology, vol. 19, n. 4, p. 425-448. http://dx.doi.org/10.1590/S1677-04202007000400011

Asada, K. (1992) - Ascorbate peroxidase: a hydrogen peroxidase-scavenging enzyme in plants. Physiologia Plantarum, vol. 85, n. 2, p. 235-241. https://doi.org/10.1111/j.1399-3054.1992.tb04728.x

Bettiol, W. (1991) - Componentes do controle biológico de doenças de plantas. In: Bettiol, W. (Ed.) - Controle biológico de doenças de plantas. Jaguariúna: Embrapa-CNPMA, p. 1-5.

Boudjeko, T.; Omokolo, N.A.; Driouich, A. \& Balangé, A.P. (2005) - Peroxidase and pectin methylesterase activities in cocoyam (Xanthosoma sagittifolium L. Schott) roots upon Pythium myriotylum inoculation. Journal of Phytopathology, vol. 153, n. 7-8, p. 409-416. https://doi.org/10.1111/j.1439-0434.2005.00993.x

Bradford, M.A. (1976) - A rapid and sensitive method for the quantification of microgram quantities of protein utilizing the principle of protein-dye binding. Analytical Biochemistry, vol. 72, n. 1-2, p. 248-254. https://doi.org/10.1016/0003-2697(76)90527-3

Cai, C.; Xu, C.; Li, X.; Ferguson, I. \& Chen, K. (2006) - Accumulation of lignin in relation to change in activities of lignification enzymes in loquat fruit flesh after harvest. Postharvest Biology and Technology, vol. 40, n. 2, p. 163-169. https://doi.org/10.1016/j.postharvbio.2005.12.009

Cakmak, I.; Strobe D. \& Marschner, H. (1993) - Activities of hydrogen peroxide-scavenging enzymes in germinating wheat seeds. Journal of Experimental Botany, vol. 44, n. 1, p. 127-132. https://doi.org/10.1093/ $\mathrm{jxb} / 44.1 .127$

Campos, A.D.; Hampe, M.M.V.; Ferreira, A.G.; Antunes, I.F. \& Castro, L.A.S. (2009) - Indução de resistência sistêmica à antracnose em feijoeiro-comum pela raça delta avirulenta de Colletotrichum lindemuthianum. Pesquisa Agropecuária Brasileira, vol. 44, n. 1, p. 15-21.

Cañal, M.J.; Tamés, R. S. \& Fernández, B. (1988) - Peroxidase and polyphenoloxidase activities in Cyperus esculentus leaves following glyphosate applications. Plant Physiology, vol. 74, n. 1, p. 125-130. https://doi. org/10.1111/j.1399-3054.1988.tb04952.x 
Carré-Missio, V.; Rodrigues, F.A.; Schurt, D.A.; Rezende, D.C.; Moreira, W.R.; Korndörfer, G.H. \& Zambolim, L. (2012) - Componentes epidemiológicos da ferrugem do cafeeiro afetados pela aplicação foliar de silicato de potássio. Tropical Plant Pathology, vol. 37, n. 1, p. 50-56. http://dx.doi.org/10.1590/S1982-56762012000100006

Carvalho, M.P.; Zanão Júnior, L.A.; Ávila, V.T. \& Alvarez, V.H. (2008) - Características fisiológicas de plantas de arroz cultivadas em solução nutritiva com fontes de silício. In: Congresso Brasileiro de Botânica. Natal, Sociedade Brasileira de Botânica.

Catalani, G.C.; Vieira, M.R.; Camargos, L.S.; Bomfim, N.C.P. \& Agustini, J.A. (2016) - Effects of potassium silicate application on papaya plants in the twospotted spider mite population. Revista Brasileira de Fruticultura, vol. 39, n. 2, e. 840. http://dx.doi.org/10.1590/0100-29452017840

Chakraborty, S.; Tiedemann, A.V. \& Teng, P.S. (2000) - Climate change: potential impact on plant diseases. Environmental Pollution, vol. 108, n. 3, p. 317-326. https://doi.org/10.1016/S0269-7491(99)00210-9

Daly, J.M. (1976) - The carbon balance of diseased plants: changes in respiration, photosynthesis and translocation. In: Heitefuss, R. \& Williams, P.H. (Eds.) - Physiological plant pathology. Berlin, SpringerVerlag. p. 450-479. https://doi.org/10.1007/978-3-642-66279-9_18

Datnoff, L.E.; Rodrigues, F.A. \& Seebold, K.W. (2007) - Silicon and Plant Nutrition. In: Datnoff, L.E.; Elmer, W.H. \& Huber, D.M. (Eds.) - Mineral nutrition and plant disease. Saint Paul MN, ASP Press. p. 233-246.

Duniway, J.M. \& Durbin, R.D. (1971) - Some effects of Uromyces phaseoli on the transpiration rate and stomatal response of bean leaves. Phytopathology, vol. 61, n. 1, p. 114-119. https://doi.org/10.1094/Phyto-61-114

Epstein, E. (1999) - Silicon. Annual Review of Plant Physiology and Plant Molecular Biology, vol. 50, p. 641-664. https://doi.org/10.1146/annurev.arplant.50.1.641

Evans, H.C. (1981) - Pod rot of cacao caused by Moniliophthora roreri. Phytopathological Paper n. 24, CMI.

Farah, A. \& Donangelo, C.M. (2006) - Phenolic compounds in coffee. Brazilian Journal of Plant Physiology, vol. 18, n. 1, p. 23-36. http://dx.doi.org/10.1590/S1677-04202006000100003

Gomes, F.B.; Moraes, J.C.; Santos, C.D. \& Antunes, C. S. (2008) - O uso do silício como indutor de resistência em batata a Myzus persicae (Sulzer) (Hemiptera: Aphididae). Neotropical Entomology, vol. 37, n. 2, p. 185190. http://dx.doi.org/10.1590/S1519-566X2008000200013

Guerra, A.M.N.M.; Rodrigues, F.A.; Lima, T. C.; Berger, p. G.; Barros, A. F. \& Silva, Y.C.R. (2014) - Capacidade fotossintética de plantas de algodoeiro infectadas por ramulose e supridas com silício. Bragantia, vol. 73, n. 1, p. 50-64. http://dx.doi.org/10.1590/brag.2014.010

Grewal, T.S.; Dhillon, M.; Sampuran, K. \& Sharma, I. (1999) - Role of stomata and hairs in resistance/ susceptibility of wheat to Karnal bunt. Journal of Mycology and Plant Pathology, vol. 29, n. 2, p. 217-221.

Hattori, T.; Inanaga, S.; Araki, H.; An, P.; Morita, S.; Luxova, M. \& Lux, A. (2005) - Application of silicon enhanced drought tolerance in Sorghum bicolor. Physiologia Plantarum, vol. 123, n. 4, p. 459-466. https://doi. org/10.1111/j.1399-3054.2005.00481.x

Korndörfer, G.H.; Pereira, H.S. \& Nolla, A. (2004) - Análise de silício: solo, planta e fertilizante. Boletim Técnico 2.

Ma, J.F.; Miyake, Y. \& Takahashi, E. (2001) - Silicon as a beneficial element for crop plant. In: Datnoff, L.E.; Korndörfer, G.H. \& Snyder, G. (Eds.) - Silicon in Agriculture. New York, Elsevier Science, p.17-39.

Macagnan, D.; Romeiro, R.S.; Baracat-Pereira, M.C.; Lanna-Filho, R.; Batista, G.S. \& Pomella, A.W.V. (2008) - Atividade de enzimas associadas ao estado de indução em mudas de cacaueiro expostas a dois actinomicetos residentes do filoplano. Summa Phytopathologica, vol. 34, n. 1, p. 34-37. http:/dx.doi.org/10.1590/ S0100-54052008000100007

Machado, E.C.; Oliveira, R.F.; Ribeiro, R.V.; Medina, C.L.; Stuchi, E.S.; Marin, F.R.; Silva, J.A.B. \& Silva, S.R. (2006) - Fluxo da seiva e fotossíntese em laranjeira 'Natal' com clorose variegada dos citros. Pesquisa Agropecuária Brasileira, vol. 41, n. 6, p. 911-918.

Menezes, S. \& Carmo-Neto, D. (1993) - A Modernização da agribusiness do cacau. Salvador, Cargill. 1993, 180 p.

Parida, A.K.; Das, A. \& Mohanty, B.P. (2004) - Defense potentials to $\mathrm{NaCl}$ in a mangrove Bruguiera parviflora: differential changes of isoforms of some antioxidant enzymes. Journal of Plant Physiology, vol. 161, n. 5, p. 531-542. https://doi.org/10.1078/0176-1617-01084

Pascholati, S.F. \& Leite, B. (1994) - Mecanismos bioquímicos de resistência à doenças. In: Luz, W.C. (Ed.) Revisão Anual de Patologia de Plantas. Passo Fundo, p. 1-51. 
Polanco, R.L.; Rodrigues, F.A.; Nascimento, J.T.K.; Cruz, M.F.A.; Curvelo, C.R.S.; Da Matta, F.M. \& Vale, F.X.R. (2014) - Photosynthetic gas exchange and antioxidative system in common bean plants infected by Colletotrichum lindemuthianum and supplied with silicon. Tropical Plant Pathology, vol. 39, n. 1, p. 35-42. http://dx.doi.org/10.1590/S1982-56762014000100005

Pinto, D.G.; Aguilar, M.A.G.; Souza, C.A.S.; Silva, D.M.; Siqueira, P.R. \& Cao, J.R. (2011) - Fotossíntese, crescimento e incidência de insetos-praga em genótipos de cacao pulverizados com silício. Bioscience Journal, vol. 30, n. 3, p. 715-724.

Roulin, S. \& Buchala, A. J. (1995) - The induction of $\beta$-1,3-glucanase and other enzymes in groundnut leaves infected with Cercospora arachidicola. Physiological and Molecular Plant Pathology, vol. 46, n. 6, p. 471-489. https://doi.org/10.1006/pmpp.1995.1036

Santos, G.R.; Rodrigues, A.C.; Bonifacio, A.; Junior, A.F.C. \& Tschoeke, P.H. (2014) - Severidade de antracnose em folhas de sorgo submetido a doses crescents de silício. Revista Ciência Agronômica, vol. 45, n. 2, p. 403408.

Siegrist, J.; Orober, M. \& Buchenauer, H. (2000) - DL-b- aminobutyric acid-mediated enhancement of resistance in tobacco mosaic virus depends on the accumulation of salicylic acid. Physiological and Molecular Plant Pathology, vol. 56, n. 3, p. 95-106. https://doi.org/10.1006/pmpp.1999.0255

Silva, S.D.V.M.; Luz, E.D.M.N.; Gramacho, K.P.; Albuquerque, P.S.B. \& Bezerra, J. L. (2000) - Standardization of the belt system method to assess cacao genotypes to witches' broom resistance. In: Proceedings 13th International Cocoa Research Conference, Kota Kinabalu, Malaysia.

Silva, I.L.S.S.; Resende, M.L.V. de; Júnior, P.M.R.; Costa, J.C.B.; Camilo, F.R.; Baptista, J.C. \& Salgado, S.M.L. (2008) - Efeito de nutrientes combinados com indutores de resistência na proteção contra a vassoura-debruxa no cacaueiro. Ciência Agrotécnica, vol. 32, n. 1, p. 61-67. http://dx.doi.org/10.1590/S1413-70542008000100009

Soratto, R.P.; Fernandes, A.M.; Crusciol, C.A.C. \& Souza-Schlick, G.D. de (2012) - Produtividade, qualidade de tubérculos e incidência de doenças em batata, influenciados pela aplicação foliar de silício. Pesquisa Agropecuária Brasileira, vol. 47, n. 7, p. 1000-1006. http://dx.doi.org/10.1590/50100-204X2012000700017

Souza, J.V.de; Rodrigues, C.R.; Luz, J.M.Q.; Carvalho, P.C. de; Rodrigues, T.M. \& Brito, C.H. (2010) - Silicato de potássio via foliar no milho: fotossíntese, crescimento e produtividade. Bioscience Journal, vol. 26, n. 4, p. 502-513.

Stangarlin, J.R.; Pascholati, S.F. \& Labate, C.A. (2000) - Efeito de Phaeoisariopsis griseola na atividade de ribulose-1,5-bbisfosfato carboxilase-oxigenase, clorofilase, $\beta$-1,3-glucanase e quitinase em cultivares de Phaseolus vulgaris. Fitopatologia Brasileira, vol. 25, p. 59-66.

Vance, C.P.; Kirk, T.K. \& Sherwood, R. (1980) - Lignification as mechanism of disease resistance. Annual Review of Phytopathology, vol. 18, p. 259-288. https://doi.org/10.1146/annurev.py.18.090180.001355

Yoruk, R. \& Marshall, M.R. (2003) - Physicochemical properties and function of plant polyphenol oxidase: a review. Journal of Food Biochemistry, vol. 27, n. 5, p. 361-422. https://doi.org/10.1111/j.1745-4514.2003.tb00289.x

Zambolim, L.; Pereira, S.C.; Rodrigues, F.A.; Carré-Missio, V. \& Oliveira, M.G.A. (2009) - Aplicação foliar de silício na resistência da soja à ferrugem e na atividade de enzimas de defesa. Tropical Plant Pathology, vol. 34, n. 3, p. 164-170. http://dx.doi.org/10.1590/S1982-56762009000300005

Zanão Júnior, L.A.; Fontes, R.L.F. \& Ávila, V.T. (2009) - Aplicação do silício para aumentar a resistência do arroz à mancha-parda. Pesquisa Agropecuária Brasileira, vol. 44, n. 2, p. 203-206. http://dx.doi.org/10.1590/S0100$204 \times 2009000200013$

Zanetti, L.V.; Milanez, C.R.D.; Gama, V.N.; Aguilar, M.A.G.; Souza, C.A.S.; Campostrini, E.; Ferraz, T.M. \& Figueiredo, F.A.M.M.A de (2016) - Leaf application of silicon in young cacao plants subjected to water deficit. Pesquisa Agropecuária Brasileira, vol. 51, n. 3, p. 215-223. http://dx.doi.org/10.1590/S0100-204X2016000300003 